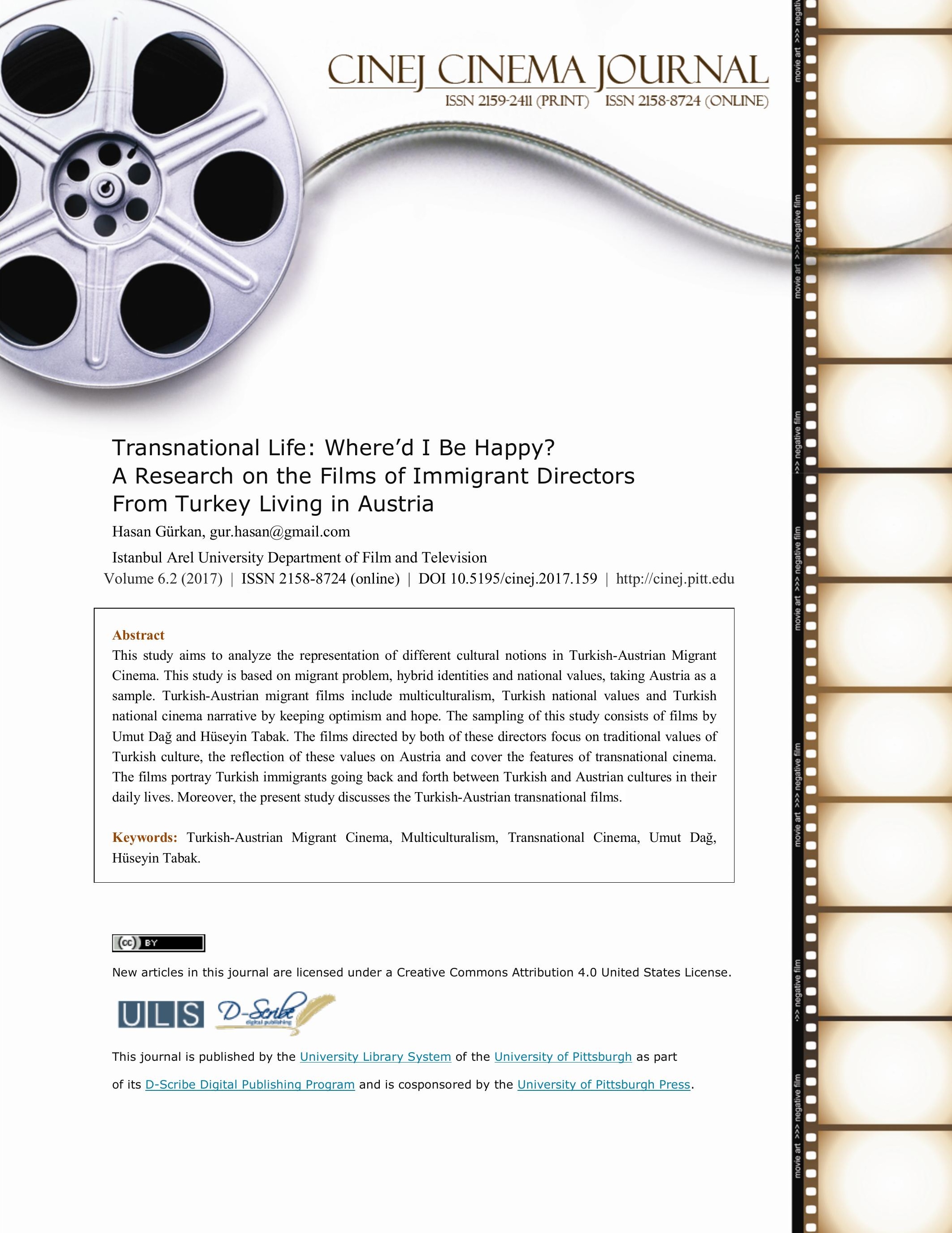




\title{
Transnational Life: Where'd I Be Happy? \\ A Research on the Films of Immigrant Directors \\ From Turkey Living in Austria
}

\author{
Hasan Gürkan
}

\section{Introduction}

This study discusses migration and transnationalism, thus I seek the answer to this question through this research: "How is transnationalism presented in the films directed by Umut Dă̆ and Hüseyin Tabak?" By doing it, I will be discussing transnational cinema through the three films. However, within the concept of transnationalism I aim to answer other two questions: "How are the Turkish and the Austrian cultures added together?" and "What is the day to day lives of immigrant ${ }^{1}$ Turks with regards to transculturalism between Turkish and Austrian cultures after migration?" based on the films directed by Dağ and Tabak. Although the history of migration from Turkey to Austria is as long as the history of migration from Turkey to Germany, however, this case has not been discussed in academic area much more than the migration to Germany. Inherently, its cultural aspects have not been analyzed sufficiently. Therefore, in this paper, I will be addressing the cultural encounters through the three films. In

\footnotetext{
${ }^{1}$ Hüseyin Tabak says "There are various generations in Austria. The families are the first that came to Austria by the 1960 s and 1980s. Many of these families were invited as a worker by Austria government. The workers and their families settle down Austria making the necessary things. Their kids went to the schools and they integrated Austria's life. Austria stopped the labor recruitment by the 1990s; however, the migration was going on from Turkey. The life was too hard for those who were coming from Turkey to Austria because it was a big problem to find a job for the immigrants. The integration of the immigrants that came from Turkey to Austria on the 1990s was harder. It was not possible for their kids getting used to German language and riding high at their school. On the 1970s and 1980s, political-intellectual immigrants were higher than on the 1990s, therefore I can say that the immigrants from the countryside of Turkey to Austria. On the other hand, many young people from Turkey to Austria to get the education in the last years. This is hopeful because a new Turkish generation has occurred with those young people" (Gürkan, 2015: 162).
} 
order to analyze the films, this study will start with a discussion of the notion of the migration and the situation of the migrant directors within the scope of the transcultural notion. Then, I will discuss what transnational cinema exactly addresses.

This study provides the examples of how different identities are represented in the three films, cultural texts and accordingly provides examples of identities analysis and critique. Multiculturalism affirms the worth of different types of culture and cultural groups, claiming, for instance, in the films by these directors, the immigrant people's identity issue and how they are Turk, Kurd, Austrian or other ethnic identities they feel close to, being a gay, and other oppressed and different voices have their own validity and importance.

In this paper, I will be trying to answer how these films (Kuma-Second Wife, 2012 - and Betondaki Çatlaklar - Cracks in Concrete, 2014- directed by Umut Dağ / Güzelliğin On Par' Etmez - Your Beauty is Utterly Worthless, 2012- directed by Hüseyin Tabak ${ }^{2}$ ) express cultural differences by using transnationalism and by following traditional concepts of culture. Films are chosen as the sampling of the study. There is a relationship between director, film, audience and social structure. Cinema sociology is the whole of one or a few of the relationships between these four basic elements in terms of scope and subjects, and occasionally the work of tackling all of them. Cinema is multi-dimensional with its elements such as economic, social, ideological, and psychological. The creation of the director -as it is in the other artistic works- is a matter of liberation. These following questions are important the relationship between directors, society and audience: How free can director be? How can s/he escape the obligations of "what can be said" and express what s/he would like to say through the film? In other words, is there a way to

\footnotetext{
2 Tabak's another full-length film "Das Pferd auf dem Balkon (A Horse on the Balcony) 2012 is about an Austrian boy (Mika) who has autism. Mika does not have any friends, and he lives with his mother. After some time, Mika and his only friend Dana find a horse living on their block and form a bond with the animal and its owner. This film by Tabak is neither about migration nor transnationalism, nor does it include Turkish immigrants or Turkish values. Due to these reasons, A Horse on the Balcony is not examined as a sample of this study.
} 
escape the necessities of what is called "cinematographic culture"? Cinema, which has very rich possibilities for narration, is more influenced by the obstacles of the censorship mechanism than by the other fields of art. The films will necessarily reflect the locals, the morality of civilization, the sacred and unholy taboos of social life categories, values, interreligious authority relations, roles, cultural values, etc.

\section{Discussing Transnational Cinema}

Cinema, itself, is multinational, not national in the contemporary world because of globalism. According to the United Nations (Behlil, 2007: 17), transnational companies can be defined as size, oligarchic nature, a large number of foreign subsidiaries and branch offices, and origins in the developed countries. However, at this stage, it is possible to state that transnationalism affects the films, which are accepted as the cultural artifacts. The films, which involve particular ideologies, messages, and cultural codes, are affected by transnational dynamics. Transnational cinema has been discussed in film studies discipline over the last decades. Natasa Durovicova and Kathleen Newman's World Cinemas: Transnational Perspectives (2009), Elizabeth Ezra and Terry Rowden's Transnational Cinema: The Film Reader (2006), Andrew Nestingen and Trevor Elkington's Transnational Cinema in a Global North: Nordic Cinema in Transition (2005), and Hamid Naficy's An Accented Cinema: Exilic and Diasporic Filmmaking (2001), are the main references in transnational cinema. In addition to this, Kenneth Chan (2009), Leon Hunt and Wing-fai Leung (2008), Ramindar Kaur and Ajay Sinha (2005), Meaghan Morris et al. (2005), Emine Uçar İlboğa (2014) also discuss transnational cinema with the national cinema perspective.

Elizabeth Ezra and Terry Rowden (2006) define transnationalism as "the global forces that link people or institutions across nations". Ezra and Rowden (2006) discuss transnationalism in terms of cinema as "Hollywood's domination of world film markets". In this sense, domination of Hollywood through the world film market is a significant definition. Therefore, it 
is impossible to mention the existence of national cinema with this definition. Every director in the film industry is affected by transnational interaction. Transnationalism, as a cultural form, was particularly discussed in the 1990s (Kearney 1995; Portes 1999a; Smith and Guarnizo 1998; Vertovec and Cohen 1999).

The approaches in migration theory define the ways of lives of immigrants' transnational communities. Alejandro Portes (1999a: 812) notes that such immigrant communities are networks of political boundaries created by immigrants in search of economic progress and social recognition. Through these networks, immigrants can live a dual life. Immigrants and their children are bilingual and can easily move between different cultures; they often live in two countries and maintain economic, political and cultural interests, which are both required to be found. In this context, the issues that immigrant directors deal with are not independent of this reality they live in. On the other hand, Hamid Naficy (1996) states transnationalism affects the directors who produce films, which are formed with the features of both national and global values. In this sense, transnational cinema forms the national features such as cultural identity or diasporic experience. In addition to this, transnational cinema focuses on a protagonist, but on the other hand, it deals alienation, diasporic issues, and the sense of belonging as a difference from the mainstream cinema. On the other hand, transnational cinema always deals with not only a protagonist through the films. It shows a few protagonists and their host and home cultures' problems and connections between local and global.

Furthermore, is it possible to mention about an independent transnational genre in this sense? As I mentioned before, if transnationalism is affected by globalism, created by economic, cultural, and politics dynamics, then do the transnational exchanges and the circulation of films create a new cultural sphere from the national values or are the hybrid values seen in the mass media products such as films? According to Garcia Canclini (as cited 
in Alvaray: 2013), the idea of hybridity serves to map out cultural transformations at the material and discursive levels. Therefore, I will be discussing with the perspective of transnational cinema and transnational identity further in this paper.

\section{Historical Perspective of Migration to Austria and Turkish-Austria Cinema}

Turkish-Austrian migrant films dominantly promote multiculturalism, transculturalism and carry a certain degree of optimism and hope and many of them deeply integrate the larger narrative of Turkish national cinema. In addition to this, it is beneficial to mention a brief history of Turkish Austrian migration as well as its cinematic context, in terms of production, distribution and reception.

My earlier study (2017) expresses the history of migration from Turkey to Austria in Migration and Alienation: "When and Where Have I Changed?" - An Analysis through TurkeyAustrian Migration Film. I mention that the labor migration from Turkey to Europe started in 1956 following an agreement signed by Turkish and German governments to meet the labor force deficit in 1961. I summarize the migration process as follows: After World War II, Austria was included in the USA's Marshall Plan. By this way, Austria, just like Germany, started to develop economically. Following the concluding agreement with Austria, labor migration from Turkey to Austria started. Turkish immigrants' numbers increased every ten years. In the beginning of migration, immigrants were men, but in the following years the percentage of women and children started to increase because of family reunion. In addition to this, Deborah Shaw (2013) discusses in her article Deconstructing and Reconstructing 'Transnational Cinema'. According to her transnational cinema components that we examine Turkish-Austrian transnational cinema seems possible to reach the following conclusions:

$\begin{array}{ll}\text { Kuma (Second Wife): } & \begin{array}{l}\text { Production Company / Wega Film } \\ \text { Distribution Company / Filmladen }\end{array} \\ \text { Cracks in Concrete: } & \text { Production Company / Wega Film }\end{array}$




\section{Distribution Company / Filmladen}

Your Beauty is Utterly Worthless: Production Company: Dor Film

Distribution Company: Barnsteiner Film

It is hard to mention that Turkish-German cinema's films have achieved great success on the film market. As seen on the table above, PR activities, distribution and the policies regarding the films are exhibited in how many countries and in how many cinema halls play an important role for filmmaking. As Zeynep Çetin Erus (2007) states that distributor companies determine the films to be shown at cinema halls and their time and duration. Therefore, it is a must to reach the large masses for the Turkish-Austrian cinema's films to get the strongest distributor companies' lists. When there are few distributors and they are integrated with the distributors' production companies, the assets of the producers apart from this are at the mercy of the distributors. On the other hand, as Shaw discusses what is needed for a film is mentioned as transnational are multiple locations, cultural exchange, and diasporic filmmaking.

The history of Turkish-Austrian cinema has no long past. The reflection of the migration from Turkey to Austria, which has a history of more than 50 years, has been able to locate on the silver screen after the 2000s. When mentioned Turkish-Austrian cinema, Umut Dağ and Hüseyin Tabak and their films, which are examined in this study, can be discussed. Unlike these two names as well, there is another director whose name is Kenan Kılıç who lived in Turkey until the age of the 20s in Turkey, however, then had to move to Austria in the beginning the 1980s, additionally contributed with the two films to Turkish-Austrian cinema. Kenan Kilıç's fictional film entitled the Night Travelling in 2002 and a documentary production entitled Away from home in 2008 are the basis films of Turkish-Austrian cinema. I also indicate regarding the film The Night Travelling (2017) directed by Kılıç as follows: "The film Night Travelling refers to social problems such as immigration, moving up into a higher class, financial troubles and unemployment to the power, center-periphery relations on the other hand." For this reason, unlike Dağ and Tabak, Kılıç tries to reflect the problem of 
integration and adaptation processes of the Turks living in Austria. With all these, I can clearly state that Turkish-Austrian cinema is not as rich and powerful place as Turkish-German cinema in terms of production, distribution and audience. Daniela Berghain (2009) notes that the characters, in the Turkish-German cinema films, travel from Turkey to Germany or in the opposite direction and these kinds of films meet with the audience as a kind of very popular genre in recent years. Nevertheless, the young Turks in Germany had a significant role behind the revival of German cinema in the late 1990s. Especially at the beginning of the 2000s, Fatih Akin's Duvara Karşı and the other film-makers such as Ayse Polat, Yüksel Yavuz, Thomas Arslan, Züli Aladağ, Sulbiye Günar are perceived as the next expected auteur wave (Berghain, 2009). Moreover, the Turkish-German cinema films can be analyzed considering both the peculiar position of Turkey and Germany's cultures. In this way, it is also possible for these films to reach cross-border audiences. A similar situation is valid for the Turkish-Austrian cinema's films; unfortunately, I would say they could not show similar success. I agree with Berghan's comment (2009) about the Turkish-German cinema films: "How deeply intertwined Turkish and German film cultures have become over the past decade or so manifests itself in the heated debates about belonging, national identity and citizenship triggered by some of the films and their creators."

In addition to this, as it is in the Turkish-German cinema, the Turkish-Austrian cinema is produced through the paradigm of representation. At this point, as Naficy (2001) and Fincham (2008) point out, it is possible to say that the audience meet with the films, which tell about the real life struggles of fictional characters. While Berghan (2009) states that the Turkish-German films reflect these problems, in short, social and cultural developments, Burns (2007) and Rings (2008) point out, these films tell the issues about living together. Accordingly, as the Turkish-German cinema does, the Turkish-Austrian cinema also raises immigration, alienation, loneliness, identity, integration and belonging problems (Gürkan, 2017). 
Turkish-Austrian cinema's characters have the hybrid cultural features just like the other characters who are the subjects of the cultural encounters in Europe. These characters are the part of the labor migration or the political asylum. While the characters of Turkish-Austrian cinema resist the hybrid (the characters that belong to the first generation), the others accept the hybridity and they are pleased with the cultural encounters (the characters who represent the second and the third generation, Gürkan, 2016). Traditional defensive against hybridity is more prevalent in the first generation coming with labor migration. On the other hand, the second and the third generations have been affected by the Austrian culture. The second and the third generations with their hybrid identities are represented by the more open-minded characters for the cultural encounters. This conflict through the characters in the films is fed with the logic, which positions the cultures as pure and homogeneous and the tensions among the expressions, which are opened for the cultural dialog.

\section{Transnationalism and Cultural Identity: Samples from the Films}

Umut Dağ's first full-length film Kuma (Second Wife, 2012) has very interesting transcultural values. Traditional Turkish (Anatolian) customs are integrated into the plot of the film. One of these customs is the tradition of "Kuma" (being the second wife of a man), which is still a popular phenomenon, particularly in Eastern Turkey.

Transculturalism is a notion that blends different cultures; on a single platform. It includes philosophical and cultural views and opinions concerning the concept of "intercultural" (Baytekin, 2006: 80). This film is a depiction of transculturalism as it shows how a culture's values and norms are related or perceived by the different cultures. As transculturalism removes cultural borders it also serves scientificity in terms of entitling new formation. Many cultural norms in the film such as being a second wife, virginity, entering the nuptial chamber, protecting the whole family after herself, etc., show the differences among the societies. For example, 
second wife tradition is not valid in the Austrian society, or all Turkish characters start their talk with "in the name of God", and for men and women sit separately (for example, in the film, when the neighbors and the relatives come to celebrate Hasan's and Ayşe's wedding, all the women and the men sit separately; the women at the kitchen, and the men in the living room) show how Turkish culture is more different than Austrian. According to Bauböck (2002), current modern ideologies exclusively emphasizes that culture does not have a homogeny structure, in contrast, the former beliefs. Transculturalism, which is used in order to express new notions and facts in the stages formed by the different cultures, gives hint to the modern society in terms of the approach to the different societies and presents that all the cultures have been interaction and communicating each other against to the squeeze of one-culture and homogeny. These scenes are the representation of transnationalism in the film.

The director Umut Dağ notes that "Turkish society places more emphasis than others on outward appearances, especially in a foreign country. The audience sees few native Austrians but people are always aware of the non-Turkish, non-Muslim society that surrounds this immigrant enclave - not least the way some family members switch fluently between Turkish and German" (Kemp, Film of the Week: Kuma: 7 September 2015). In Kuma, the culture-clash contradictions are shown most clearly in elder sisters, Kezban and Nurcan, who displace their resentment of their controlling mother into a vindictive treatment of Ayşe. Both speak fluent German, which they flaunt, using it as a secret language in her presence; but when she's caught having sex with a work colleague, they readily invoke traditional values and demand she must be sent back to Anatolia for having 'brought shame' on the family. In fact, this situation can be adapted to the description of Wolfgang Welsch (1999). Transcultural studies just search the traces of one cultures' items in different cultures and /or observe the transitions of this unique structure into the second or the third cultures. For Welsch (1999), transculturalism occurred as a result of the encounter of two different cultures or two opposite cultures through disappearing of the borders. In the film, all of these situations are a kind of representation of two different/opposite cultures. 
According to Portes et al. (1999), transnationalism is an interaction between many lands, cultures, and groups. Transnationalism is the creation of new chances for belonging to a new culture after the identities and collective formations within the political, economic, and cultural links. In this sense, all the immigrant characters in Kuma and transnational social areas reflect social relations happening in line with the regular lives and actions of the immigrants find their places beyond the geographical borders.

Umut Dağ's second film Cracks in Concrete (Risse im Beton, 2014) is about Ertan, a former convict, who killed an Austrian guy almost 10 years ago and was sentenced to imprisonment. According to Vertovec (1999a), the differences in the notion of culture are the extrication in terms of ideological, vocational, social or gender distinction of the members of the society. Transculturalism allows the individual to be differentiated. Transculturalism has been one the basic notions, such as education, economy, politics and cultural areas that include “foreigner" notions' of exchange (Sassen: 1998). For Alois Wierlacher (2003: 25), as transculturalism condenses upon the differences of culture, it must pull away from the borders of culture at the same time. The most important element to be able to go beyond the differences and dialog between two cultures can be established with this method. In the film Cracks in Concrete, as a minority group, Turks are represented as a subclass. However the film just shows the representation of subcultures in Austrian society, so the audience can see the other groups as a keen through the film. Thereby, as Sassen (1998) mentions the notion of "foreigner" occurs in this cultural area in the film. In Cracks in Concrete, it is possible to see a more hybrid culture because all Turkish characters (Ertan, Y1lmaz, even Mikail) live as Westerners (e.g. once Ertan enters his mother's home and proceeds to the living room, the audience sees the photo of Ertan's and his elder brother's circumcision feast on the wall). This scene basically shows that Ertan's family gets into a groove because the circumcision ceremony is a piece of Islam. 
In today's world, due to the migration, economic/cultural union and addiction, the current cultures may be seen as hybrid cultures. Homi Bhabha (1990) developed the concept of "cultural difference" in opposition with that of "cultural diversity". In this sense, Bhabha (1990) states hybridity as the central focus of this new conception of identity. According to Bhabha (1990), this hybridity is not a dominant identity, which occupies the colonized identity. To exemplify, Mikail wants to be a hip star, Y1lmaz behaves like a mafia, the daily conversation between Mikail and his friends / Mikail and Ertan / Ertan and Y1lmaz differs from that of similar groups in Turkey. In fact, this case corresponds to hybrid cultures because it is hard to see Afro-American communication style in Turkish culture or in Austrian culture. The film shows that all the cultures in the world have been losing their homogeneity, going beyond their borders and described as hybridization. As Hendrik Blumentrath states, (2007: 16-17) current cultural relations are defined as interfering and diverse. Hereby "a new universal culture" occurs with the disappearance of borders among cultures comprising transculturalism. In the film, immigrant movements can be materialized in different geographical areas such as from Turkey to Austria. Coming and going are discussed between the country left behind and the country lived in. Riccio (2001 states transnational areas emerge with these kinds of movements. Immigrants leave "national culture" slowly and move towards the realities of political, economic and social life with more international movements. This case is shown in Cracks in Concrete with the differences of the immigrants. The characters represented neither belong to Turkish culture nor Austrian culture. Particularly, the effects of globalism and transnationalism, discussed since the 1980s, are not only limited with the size of mass media and capital, but also with people's lives and the new approaches regarding their living conditions. As Moosmüller (2006) points out wayfaring mixed cultural phenomena have become a current issue, as in the example of Cracks in Concrete. Moosmüller (2006: 40) mentions that "the world of there and here" were a thing of the past. It is easy to see in Cracks in Concrete. Ertan, Y1lmaz, Mikail or Nuri's lives neither belong to the present (or their current 
lives $=$ Austria) nor to the past (or their past lives or their roots $=$ Turkey). Their lives are a kind of a new world which take part in "extended social areas". As Castles (2000) states "all of us goes willingly or unwillingly, with self-selected in a variable world". This saying fairly fits Cracks in Concrete. The immigrant characters cannot do their choices through the film. The system somehow pushes them backward and forward. Mikail constantly borrows money from Y1lmaz, since he wants to release a hip-hop album and be a star, but he cannot succeed because it is beyond his power.

Wolfgang Welsch (2009) cites that 'both there and here' in transnationalism theory, modern cultures are formed with the various ways of life concreting with each other and engaging with each other. Thus it is impossible to mention the borders of national cultures. This can be seen in Cracks in Concrete. The immigrants' ways of lives do not come to an end; on the contrary, they can reach other cultures by passing over these borders. In Cracks in Concrete, the representation of cultures is not close and does not fit only one national-culture; multi-layered identities are formed in the cross-border line. In this manner, Welsch (2009) notes that interculturalism and multiculturalism discussions do not take away only one cultural understanding. Despite that the notions of transnationalism and transculturalism are adjusted in terms of a new understanding. Herewith, it is possible to say that the current transnational lives, interculturalism and multiculturalism are not strong enough; transculturalism is underlined in Cracks in Concrete.

Faist (2000) points out geographic places as well as social areas by mentioning the differences of social and geographic areas. Social areas include of daily life, organizations and institutions. Faist (2000) expresses that in three different circumstances: In daily-life conditions, when a Peruvian peasant who lives in a village, a manager who live in diaspora, the unlimited doctors who work in the social area that depends on transnational organization are studied, one can face social practices, symbol systems, and a complicated relation based on 
artefact. In Cracks in Concrete, it can be seen what Pries says. When all the characters are analyzed, the social relations, based on the ordinary lives and activities, overreach the borders of geography. Transnationalism of social world in the film enables one to concrete the varieties.

The immigrant identities, which develop with the second and the third generation, established a transnational third space over the bridge between their homeland's and their host cultures. The term third space, coined by Homi Bhabha (1990), ascertained deepness in a metaphoric space where cultures meet and carried out studies in order to expand this by Bhabha (1994: 218). This case brings transnationalism together with. In the contemporary world, where the third generation of Turkish immigrants live in Austria, it is possible to observe the hybrid identities as mentioned by Bhabha. Thus, it is easy to see the term third space in the films by Umut Dağ (Kuma and Cracks in Concrete). In Kuma, Hasan, Kezban and Gülsen as the third generation characters, and in Cracks in Concrete, Mikail and his friends are the representations of the third generations. Therefore where cultures meet, the colonist authority is dominant and the new hybrid identities are created by those characters as well. As Bhabha (1990) states that global and national cultures constitute a third space and open up a cultural area by creating unsynchronized temporariness, and this third space originates from an immeasurable difference and both of the existing borders form a specific space. This is what is represented in both films.

Another director Hüseyin Tabak was born in Germany but has filmed his films in Vienna-Austria. His first full-length film Güzelliğin On Par' Etmez (Your Beauty is Utterly Worthless) is about a political refugee (Veysel's father) and his family's life. This film is about a struggle and troubles an immigrant family experience. The name of the film also comes from this poem. The lyrics of the poem as following: 
Your beauty would be utterly worthless

If I didn't love you

You couldn't find any place to entertain yourself

If there was not this home in my heart

Who would read? Who would write?

Who would unravel this knot?

Sheep would get along well with wolf

Unless thoughts vary

Your beautiful face would not be seen

This love would not be revived inside me

Rose would not be valued

If there were not lovers

I took this cry from you

This was the taste of the world

Name Veysel would not be remembered

If he did not love you.

It is not a coincidence that this poem written by Aşık Veysel is the name of Tabak's first feature film. Tabak whose origin as belonging to Turkey's eastern culture, connected to the Alevi-Bektashi tradition, thus, Aşık Veysel has reflected his films. According to Aşık Veysel, the aim of love is to reach the maşuk (beloved). As the name of Veysel is mentioned, it shows that maşuk (beloved) is in love with him. Despite this, when we think that he is a folk poet from his Bektashi tradition, it is in fact that the whole existence is the cause of God's love toward preacher Muhammed. In these lines in the poem "Name Veysel would not be remembered If he did not love you." with the pronoun "you" refer to the preacher Muhammed because it could also be used as "me" rather than "you" here. The acceptance of beauty and the determination of the concept, which is a value attributed to the beginning of the poetry is wellsuited to the understanding of "being essential beauty in existence" in Alevism. It is also meaningful to express the value given to the "love of man" and "the guest of God" in Alevism. Aşık Veysel, in his poetry, refers this expression. Moreover, love and maşuk (beloved), and the emphasis placed on the love between the two, especially God, the Prophet Muhammed and the prophet Ali. It is one of the basic assumptions of Alevis to be accepted the rose as a symbol. Aşık Veysel shows love in the last lines of the poetry as a meaning and a taste of the world. 
Love, here, can be understood both as loving maşuk (beloved) and the divine love. The demonstration of the Semah in Alevism is done to show in the "love" worship style that the ending person has heard of the eternal God. In this context, Veysel reflects one of the basic hopes of Alevism believes in his poem (Şatıroğlu, 1991).

In the film, the director, Hüseyin Tabak, shows a kind of love between the two kids (Veysel and Anna) by inserting the difficulties of the immigrants. Hüseyin Tabak, who has been hybridized and gained transnational identities, began to produce similar examples to his own identities and life practices as Umut Dağ. The film does not only tell multiculturalism, but also mentions about being an immigrant, a stranger, and belonging neither Turkish nor Kurdish/Austrian cultures. Modern literature related to the transnational and hybrid identity concepts dignify the subjects with these identities. Stuart Hall's (1991: 401-402) statements about cultural hybridism are frequently mentioned in the modern literature,

... the diaspora experience as I intend it here is defined, not by essence or purity, but by the recognition of a necessary heterogeneity and diversity; by a conception of 'identity' which lives with and through, not despite, difference; by hybridity. Diaspora identities are those which are constantly producing and reproducing themselves anew, through transformation and difference.

Tabak's film reproduces some identities. According to Hall (1991), everyone is an agent who positions himself in relation with others. It is important to untie links constructed by years of imperialism and colonization between ethnic, national and identity issues. Identity becomes instead a perpetual negotiation between different positions, a construction inflected by contingency and contest but also an expression of the agency of subjects. In the film, Aş1k Veysel and his works are seen as strong cultural values, and some dialogs between Veysel and his brother such as:

Veysel's brother: "I am so hungry! You know where our mother hides the money at home. Tell me or go and bring it to me!" Veysel: "I don't do that, you know!" Veysel's brother: "I am telling you that I am so hungry! Give your lunch in your bag at least!" 
Veysel: (just looks at his brother)

Veysel's brother: "Are you infidel? I told you that I am hungry. Let you give your lunch to me!"

Or when Veysel's teacher writes something in German on a paper, Veysel and his father go to a few Turkish neighbors to translate that paper from German to Turkish, but none of them can help. Moreover one of their neighbor's wife says that "Bayram is now performing the ritual prayers of Islam. He comes towards to the night!" All of these things (many immigrants don't speak, read, understand German but they can go on their lives somehow, Bayram and many of Muslim's religious practices, and even Veysel's brother's orison: “are you infidel?") show the identities, which live with and through, not despite, difference by hybridity. Hall (1991: 403) points out a different meaning to this cultural composition, the hybridism, which is not traditionally dignified. Hall finds a strong creativity in it since hybridism offers the opportunity to create a new, dynamic and mixed culture. It has been argued that in the globalized era the film shows that "culture" and "community" have become separated from locality.

Ayhan Kaya (2000: 66) points out Turkish youngsters create their own strategies in order to overcome the problems such as discrimination, racism, and structural exclusion. According to Kaya (2000) these problems exist with the impacts of globalization. These young people develop an identity, which is generated by the two cultures to which the youngsters are permanently experienced. The situation which can be defined as diasporic consciousness is natively an imagination occurring from the process of interaction between the local and the global, the future and the past, "there" and "here". This takes us to the presence of a sort of "double consciousness" phenomenon. In Your Beauty is Utterly Worthless, it is possible to see this. Veysel's brother is rebellious and he argues with his parents all the time, or Umut Dağ's second movie Cracks in Concrete the expectation of Mikail (being a pop-star and release a hiphop album, besides he is rebellious against to everybody) supports Kaya's thesis.

Emine Uçar İlbuğa (2010), in her significant work, notices that the youngsters' identification processes, sufferings, different orientations, rootlessness, belonging nowhere, 
omnipresence, gender roles, existence problems, love affairs, daily lives, expectations, and dreams are beyond being stuck and are shaped in the context of their multicultural, multilingual, and transnational lives; the immigrants are the groups who live in Germany. Therefore life is not easy as thought for young people born and grown up abroad. As in the films by Dağ or Tabak, the characters Hasan, Mikail, Veysel's brother have link with Turkey with their heterogeneous and multi-layered structures rather than being a homogeneous group. Hasan cannot say that he is a gay, or Mikail and Veysel's brother are hatred because they think they have had so many troubles.

In addition to above mentioned Randall Halle (2008: 167) states that the transnational normalcy of the films is based on the depiction of the new migrants: "Unlike in the nineteenth and early twentieth centuries, when emigration generally meant the loss of engagement with the country of origin, the new transnational migrants are no longer forever dislocated from their homelands." As Halle's claim regarding transnationality and acknowledgement of Veysel's brother, Ayşe, Hasan, Mikail, Ertan as transnational migrants is crucial, it is questionable whether one could call Turkey their homeland. On the other hand, following Deniz Göktürk's (2003: 180) comprehensive question: How do transnational cinemas create imaginary homelands? I urge that, Tabak's and Dağ's films and characters create an imaginary homeland in Turkey for them.

\section{Discussing an Independent Transnational Genre through Turkish-Austrian Migrant Cinema}

Cinema has been transnational since its beginning as a medium. It was invented independently and simultaneously in France and America, and spread around the world. Independent transnational cinema is a new genre that cuts through the pre-defined geographical, national, cultural, cinematic and meta-cinematic borders. Independent transnational films produced by filmmakers who have been forced to leave their homelands 
with the different historical, social and political reasons are not only a common theme, but also a new genre due to their common formal features, similar production and consumption conditions (Güzel, 2001: 42).

According to Hall (1998:42-43), "In order to construct the identity of Europe, it is needed to be passed through the pinhole of the other." The components of transnational cinema compose a very complicated dimension. Just as the other movements, genres in the history, transnational cinema does not have dependent, centralized, and hierarchical structure. The main criterion in determining the components of narrative forms of transnational cinema is that these components are used in a single film or in multiple films. Hybrid life experiences hybridize the narrative forms. Transnational cinema acts around the limits of national cinemas, genres, and narratives. These kinds of films have two or three languages, and they reflect the situation of their filmmakers' double consciousness. Their aesthetic forms are not homogeneous. Transnational cinema has cinematic narratives that are influenced by the cinema traditions of the film makers' own countries and the countries they live in.

As mentioned above in this study, these three films have transnational components. As Ezra and Rowden (2006) state transnational cinema crosses of borders of Hollywood. As known well, the American film industry -Hollywood, the first cinema, mainstream cinema - has dominated all other film cultures and modes of cinematic imagery, production, and reception since the First World War. The domination of Hollywood has affected the other national cinemas in the meantime. However, As Ezra and Rowden (2006) state, it can be seen in these three transnational films, they imagine their audiences as consisting of viewers who have expectations and types of cinematic literacy that go beyond the desire for and mindlessly appreciative consumption of national narratives that audiences can identify as their own. Ezra and Rowden (2006: 1) state that the transnational comprises both globalization - in cinematic terms, Hollywood's domination of world film markets - and the counterhegemonic responses of 
filmmakers from former colonial and Third World countries. This claim seems to urge that when we are talking about transnational cinema in these three films, either that on international release, or those which are marginalized from the global market, as long as they challenge Hollywood filmmaking approaches. According to Ezra and Rowden (2006: 4-7), just like the other transnational films, these three films focus on migration and diaspora themes and "in cultural spaces". It is possible to state that these three films are created by the sensation of loss. Veysel's unique love for Anna, disorientation and aspirations of Turkey of Veysel's elder brother in Austria; Veysel's brother's reading of the Independence March of Turkey against his father, the fact that Hasan has to hide his sexual identity, Ertan's false marriage, and the half-Turkish halfAustrian son's inattentiveness. The directors further enhance this sense of loss by focusing on the people who have been displaced.

On the other hand, I think the three films in this study, which could be evaluated in the framework of "accented cinema" discussed by Hamid Naficy. In his book, Naficy (2001) argues that the filmmakers, who are called "accented cinemas," have come from the underdeveloped countries of the world, often in exile and diaspora. In a global and post-colonial context, it is possible to state that these filmmakers, as Ezra and Rowden (2006: 109) point out, "means to insert themselves and their particular experiences of transnational consciousness and mobility into the spaces of cinematic representation and legitimation".

"Accented cinema" not only draws attention to the accents of the foreign filmmakers and the speech of the stereotypical characters, but also to the increasingly transnational practices, which have transformed the nature of filmmaking. The three films, in this paper between Turkey and Austria, discuss the problems regarding national status and cultures of the people, who live in Austria and who are entitled to European citizenship based in Turkey. The films articulate the concepts of fixed cultural identity and national cinema. In this sense, Naficy (2001: 120) mentions these valuable comments regarding the transnational filmmakers: 
"vast global economic and structural changes since World War II have ushered in the postmodern era characterized in part by massive displacement of peoples the world over, creating a veritable "other worlds" of communities living outside of their places of birth and habitus. Transnational filmmakers not only have given expression to these other worlds but also have enriched the cinemas of their home and adopted lands."

Tabak and Dağ are positioned a unique position in the film industry and cultures both in Europe and in Turkey, and therefore they benefit from the uncertainty that enriches the journey, and the possibility of self-rediscovery. In addition, the three films tell of Naficy's (2001: 291) discussion of "interstitial location", which means "located at the intersection of aesthetic systems, languages, nations, practices, cultures". For this reason, the diaspora is considered here not only as a theme written in movies but also as a stylistic element at the same time. The three films also offer "double consciousness" through the use of self-reflexivity and features from cinematic traditions and as Naficy's (2001: 22) discussion:

"This double consciousness constitutes the accented style that not only signifies upon exile and other cinemas but also signifies the condition of exile itself. It signifies upon cinematic traditions by its artisanal and collective modes of production, which undermine the dominant production mode, and by narrative strategies, which subvert that mode's realistic treatment of time, space and causality."

On the contemporary global world created by the common economic, cultural, and politics dynamics, transnational exchanges and the circulation of films create a new cultural sphere from national/and hybrid values can be seen in the mass media products in such as in these three films. As I (2015) mention that if Hollywood is dominant in the film industry, it is possible to see the reflections of Hollywood to almost all film movements on the contemporary world. All national cinemas have been affected by globalism. These effects include films' narratives, plots, and genres. When transnational cinema is evaluated as genre, trend, and narrative technique, the hybridization is inevitable. Hollywood has changed and renewed the narrative of movies in order to reach audiences, having different features and needs, as a result of the products of culture industry and global distribution channels. 


\section{Conclusion}

During late modernity, all minorities became visible in the society as Simon During (1993: 14) remarks "cultural studies became the voice of the other". While the work done by the British Cultural Studies researchers is extremely varied, what it added to the debate was the inclusion of the audience as a site of analysis and a focus on researching specific communities and cultures and how they see their world, rather than just talking messages and meanings in isolation.

Transculturalism, thus, the reinventing of new common culture is based on the meeting and the intermingling of the different peoples and cultures. In the three films the identities (Hasan in Second Wife, or Ertan in Cracks in Concrete, or Veysel's family in Your Beauty is Utterly Worthless) is not strictly one dimensional (the self), however is now described and more importantly recognized in harmony with the others. In other words one's identity is not only singular, but also multiple. As Scarpetta (cited as in Cuccioletta, 2002) stated "each person is a mosaic". Thus, Dağ's and Tabak's cinemas reflect upon Turkish familiar relations in Austria and on relations between Turkish and Austrian cultures, dealing with creolization and identity origins. In this sense, it is possible to interpret these three films as cultural analysis of recent developments of the encounter between Continental European and Middle East cultures and the representation of their rhetoric.

The films provide some cultural values out of which the immigrants characters forge their identities, their sense of selfhood, their notion of what it means to be male/female/or other sexual identity, their sense of class, ethnicity, race, nationality. On the other hand, another research question of this study is that if transnationalism is affected by globalism, then do the transnational exchanges and the circulations of films create a new cultural sphere from the national values or are the hybrid values seen in the mass media products such as films? When we consider the fact that capitalism, every period of its desire to regain profit, regenerates itself and, in doing so, benefits from the culture industry. Transnational cinema is seen as an 
alternative cinema against Hollywood and national cinema, on the other hand it can be said that it reproduces the cinematic components, which actually exist in the cinema industry with narrative, event sequencing and genre features. Therefore, it is not possible to state that there is also an independent transnational genre in Turkish-Austrian Migrant Cinema.

The films, belonged to the Turkish-Austrian cinema, are multilingual, and this feature brings them closer to the diasporic films. Another point regarding the diasporic films is the usage of the visual objects. Dağ and Tabak use the works of the landing country and cultural items in their films such as the second wife tradition or Aşık Veysel's poem. These cultural items are almost as if they are taught to promote them to other cultures, not merely values of longing. The audience meets the journey theme such as individual and real in Dağ and Tabak's films just like the other diasporic films. All characters arrive at the different ends of the films. The three kinds of the extension and the space are seen in the films directed by Dağ and Tabak. The purpose here is to reinforce the narrative in films, to ensure the harmony of form and content.

\section{BIBLIOGRAPHY}

Alvaray, L. (2013). Hybridity and genre in transnational Latin American Cinemas, Transnational Cinemas, 4 (1), 67-87.

Bauböck, R. (2002). Political community beyond the sovereign state: supranational federalism and transnational minorities, in Vertovec, S. and Cohen, R. (eds) Conceiving Cosmopolitanism: Theory, Context and Practice. Oxford: Oxford University Press.

Baytekin, B. (2006). Kuramsal ve Uygulamalı Karsılastırmalı Edebiyat ve Bilim, Sakarya Yayıncılık, Sakarya.

Behlil, M. (2007). Home Away from Home: Global Directors of New Hollywood. Amsterdam: University of Amsterdam.

Berghain, D. (2009). Introduction: Turkish-German dialogues on screen. New Cinemas Journal of Contemporary Film. 1 (3). 3-9.

Bhabha. H. K. (1990). Nation and Narration. Psychology Press. 
Bhabha. H. K. (1990). The Location of Culture. New York and London: Routledge.

Blumentrath, H. (2007). Transkulturalitat: Turkisch-deutsche Konstellationen in Literatur und Film. Munster: Aschendorff.

Burns, R. (2007). Towards a Cinema of Cultural Hybridity: Turkish-German Filmmakers and the Representation of Alterity. Debatte, 15 (1), 3-24.

Castles, S. (2000). Ethnicity and Globalization: From Migrant Worker to Transnational Citizen. London: Sage.

Chan, K. (2009), Remade in Hollywood: The Global Chinese Presence in Transnational Cinemas, Hong Kong: Hong Kong University Press.

Cuccioletta, D. (2002). Multiculturalism or Transculturalism: Towards a Cosmopolitan Citizenship. London Journal of Canadian Studies. 17 (2), 142-175.

Durovicova, N. and Newman, K. (2009). World Cinemas: Transnational Perspectives. New York and London: Routledge.

During, S. (1993). The Cultural Studies Reader. New York: Routledge.

Erus, Z. Ç. (2007). Film Endüstrisi ve Dağıtım: 1990 Sonrası Türk Sinemasında Dağıtım Sektörü” Selçuk Üniversitesi Illetişim Fakültesi Akademik Dergisi, 5-16.

Ezra, E. and Rowden, T. (2006). Transnational Cinema: The Film Reader. New York: Routledge.

Faist, T. (2000). The Volume and Dynamics of International Migration and Transnational Social Spaces. Oxford: Oxford University Press.

Fincham, V. (2008). Violence, Sexuality and the Family: Identity 'Within and Beyond Turkish-German Parameters' in Fatih Akin's Gegen die Wand, Kutluğ Ataman's Lola + Bilidikid and Anno Saul's Kebab Connection." German as a Foreign Language, 1, 40-72.

Göktürk, D. (2003). Turkish Delight-German Fright: Unsettling Oppositions in Transnational Cinema. Mapping the Margins. Eds. Karen Ross and Deniz Derman. New Jersey: Hampton Press, 177-192.

Gürkan, H. (2015). Karşı Sinema. Istanbul: Es Yayınları.

Gürkan, H. (2015). Interviews with the Two Transnational Directors: Turkish-Austrian Migrant Cinema and Its Issues". T.C. Istanbul Arel University Communication Faculty Communication Studies Journal. 8. 161-170.

Gürkan, H. (2016). I am a Stranger here, I am Foreigner: Well then Where am I from?, International Journal of Intermedia. 3 (3). 144-161.

Gürkan, H. (2017). Migration And Alienation: When \& Where Have I Changed? An Analysis through Turkey-Austrian Migration Film, (in) Diasporas and Transnational Entrepreneurship in Global Contexts, Ed.: Sanya Ojo, IGI Global Publishing. 205-218.

CINEJ Cinema Journal: Transnational Life: Where'd I be Happy? A Research on the Films of Immigrant Directors From Turkey Living in Austria 
Güzel, C. (2001). Sömürgeci Söylem ve Sinema: Kültürel Yanlılığın Sunumu. Türk Film Araştırmalarında Yeni Yönelimler 1. İstanbul: Bilim ve Sanat Yayınları

Hall, S. (1991). Old and New Identities, Old and New Ethnicities. Ed. Anthony D. King, Culture, Globalization and the World System. Binhamton, Macmillan Press, 41-68.

Hall, S. (1998) Küreselleşme ve Etniklik A.D. King, (ed..) G. Seçkin ve Ü.H. Yolsal in Kültür, Küreselleşme ve Dünya Sistemi, Ankara: Bilim ve Sanat Yayınları

Halle, R. (2008). German Film after Germany: Toward a Transnational Aesthetic. Urbana, IL: University of Illinois Press.

Homi, B. (1990). Nation and Narration 1990 and Location of Culture. New York: Routledge.

Hunt, L. and Leung, W. (2008), East Asian Cinemas: Exploring Transnational Connections on Film, London and New York: I.B. Tauris

Kaya, A. (2000). Sicher in Kreuzberg: Berlin'deki Küçük İstanbul: Diyasporada Kimliğin Oluşumu. Taksim. Istanbul: Büke Yayıncılık.

Kaur, R. and Sinha, A. J. (2005), Bollyworld: Popular Indian Cinema through a Transnational Lens, New Delhi: Sage.

Kearney, M. (1995). The local and the global: the anthropology of globalization and transnationalism, Annual Review of Anthropology, 24: 547- 65.

Kemp, Film of the Week: Kuma: 07.09.2015 "Migrant and Diasporic Cinema in Contemporary Europe" http://www.migrantcinema.net/glossary/term/accented_cinema/ (12.10.2017).

Moosmüller, A. (2007). Interkulturelle Kommunikation aus psychologischer Sicht. Alois Moosmüller (ed.), Interkulturelle Kommunikation: Konturen einer wissenschaftlichen Disziplin Münster: Waxmann Verlag GmbH.13-50.

Morris, M., S. L. Li and S. C. Ching-kiu. (2005). Hong Kong Connections: Transnational Imagination in Action Cinema, Hong Kong: Hong Kong University Press.

Naficy, H. (1996). Phobic Spaces and Liminal Panics: Independent Transnational Film Genre, in Rob Wilson and Wimal Dissanayake (eds), Global-Local: Cultural Production and the Transnational Imaginary, Durham and London: Duke University Press. 119-144

Naficy, H. (2001). An Accented Cinema: Exilic and Diasporic Filmmaking. Princeton and Oxford: Princeton University Press.

Nestingen, A. and Elkington, T. G. (2005). Transnational Cinema in a Global North. Wayne State University Press.

Portes, A. Guarnizo, L. E. (1999a). Transnational Communities. Special issue, Ethnic and Racial Studies, $22-2$. 
Portes, A. (1999). Immigration theory for a new century: some problems and opportunities, International Migration Review, 31(4): 799- 825.

Riccio, B. (2001). From "ethnic group" to "transnational community"? Senegalese Migrants' Ambivalent Experiences and Multiple Trajectories', Journal of Ethnic and Migration Studies, 27(4), 583-599.

Rings, G. (2008). "Blurring or Shifting Boundaries? Concepts of Culture in Turkish-German Migrant Cinema." German as a Foreign Language, 1, 6-39.

Sassen, S. (1998). The de facto transnationalizing of immigration policy', in Joppke, C. (ed.) Challenge to the Nation-State: Immigration in Western Europe and the United States. Oxford: Oxford University, Press. 49-85.

Şatıroğlu, A. V. (1991). Dostlar Beni Hatırlasın, Bütün Şiirleri, 9. Bask1, Der. Ümit Yaşar Oğuzcan, Özgür Yayın-Dağıtım, İstanbul.

Shaw, D.(2013). Deconstructing and reconstructing transnational cinema'. in S. Dennison (ed.), Contemporary Hispanic Cinema: Interrogating Transnationalism In Spanish And Latin American Film. Coleccion Tamesis: Serie A, Monografias, Tamesis, Woodbridge. 47-66.

Smith, M. P. and Guarnizo, L. E. (1998). Transnationalism from Below. New Brunswick, NJ: Transaction Publishers.

Uçar-İlbuğa, E. (2010). Çokkültürlülük, Ulus-ötesilik ve Kültürlerarası İletişim Yeterliği. Çankaya Üniversitesi Journal of Humanities and Social Sciences. 13 Mayıs, 163-180.

Uçar-İlbuğa, E. (2014). Fatih Akın Sinemasında Ulusötesilik. $1^{\text {st }}$ International CSMS Congress, Kocaeli, Turkey, 12-15 May 2014, Vol.1, No.10. 232-247.

Vertovec, S. and Cohen, R. (1999). Introduction, in Vertovec, S. and Cohen, R. (eds) Migration, Diasporas and Transnationalism. Aldershot: Edward Elgar. xiii- xxviii

Vertovec, S. (1999a). Introduction, in Vertovec, S. (ed.) Migration and Social Cohesion. Aldershot: Edward Elgar.. xi-xxxvii.

Welsch, W. (1999). Transculturality - the Puzzling Form of Cultures Today”, Ed.: Mike Featherstone and Scott Lash, Spaces of Culture: City, Nation, World, London. $194-213$.

Wierlacher, A. (2003). Interkulturelle Germanistik. $\mathrm{Zu}$ ihrer Geschichte und Theorie. Ed.: Wierlacher,Alois /Bogner, Andrea, Handbuch interkultureller Germanistik. Stuttgart, Weimar: Metzler. 145

\section{Acknowledgment}

This study is supported by the 2219 program under the project number 1059B191401065 of The Scientific and Technological Research Council of Turkey (TÜBİTAK). 